\title{
ANALISIS KEMENARIKAN MEDIA PEMBELAJARAN PHET BERBASIS VIRTUAL LAB PADA MATERI LISTRIK STATIS SELAMA PERKULIAHAN DARING DITINJAU DARI PERSPEKTIF MAHASISWA
}

\author{
Rivo Alfarizi K', M. Ricky Rifa'í2, Dinar Maftukh Fajar ${ }^{3}$
}

Program Studi Tadris IPA Institut Agama Islam Negeri Jember, Jember, Indonesia Author: rivoalfarizikurniawan@gmail.com

\begin{abstract}
Abstrak. Pembelajaran listrik magnet bagi program studi Tadris IPA IAIN Jember tidak hanya menitikberatkan pada teori saja akan tetapi juga praktik. Oleh karena itu, perlu dirancang praktikum vitual secara online untuk memenuhi tuntutan pembelajaran online, khususnya sebagai imbas dari pandemi Covid-19. Media pembelajaran Phet merupakan web penyedia kegiatan virtual lab yang dapat dijalankan sebagai pengganti praktikum mahasiswa tersebut. Tujuan dari penulisan ini antara lain: (1) untuk mendeskripsikan media pembelajaran Phet sebagai penyedia kegiatan virtual lab pada mata kuliah listrik magnet, (2) untuk memaparkan pandangan mahasiswa terhadap kemenarikan media pembelajaran Phet berbasis virtual lab pada materi listrik statis selama perkuliahan daring, (3) untuk merekomendasikan proses perkuliahan yang efektif berdasarkan persepsi mahasiswa menggunakan media pembelajaran Phet. Metode yang digunakan dalam penelitian ini adalah berupa survei, dengan memberikan angket kepada mahasiswa yang menempuh mata kuliah listrik magnet sebanyak 61 mahasiswa. Teknik pengelolahan data menggunakan metode analisis deskriptif kuantitatif. Hasil survei menunjukkan media pembelajaran Phet berbasis virtual lab pada materi listrik statis selama perkuliahan daring memiliki kemenarikan desain tampilan yang bagus, memiliki kemenarikan konten materi, memiliki kemenarikan isi percobaan yang bagus serta sesuai dengan kebutuhan mahasiswa. Rekomendasi yang diberikan yaitu media pembelajaran Phet dapat digunakan pada jenjang SMP, SMA dan perguruan tinggi, untuk memaksimalkan penggunaanya guru dapat memberikan buku pedoman tata cara penggunaan media pembelajaran Phet dan guru bisa memberikan tutorial menggunakan bantuan software bandicam dan youtube.
\end{abstract}

Kata kunci: daring, listrik statis, media pembelajaran, phet, virtual lab

\begin{abstract}
The study of electric magnets for the Tadris IPA IAIN Jember study program not only emphasizes theory but also practice. Therefore, it is necessary to design an online practicum to meet the demands of online learning, specifically as the impact of the Covid-19 pandemic. Phet Learning Media is a web provider of virtual laboratory activities that can be run as a student practicum training. The objectives of this evaluation include: (1) to describe the learning media of Phet as a provider of virtual lab activities in magnetic electricity courses, (2) to explain the students 'views on the attractiveness of learning media 3) to study the effective lecturing process on students' perceptions using media Phet learning. The method used in this study consisted of a survey, by giving questionnaires to students who studied electric magnet courses as many as 61 students. Data management techniques using quantitative descriptive analysis methods. The survey results show Phet based virtual media learning media on statistical electrical materials during lectures dare to have a good design, have interesting content material, have interesting experiment content that is good according to student needs. The recommendation given is Phet learning media can be used at junior high, high school and college levels, to maximize its use the teacher can provide manuals on how to use the Phet learning media and the teacher can provide tutorials using bandicam and youtube software.
\end{abstract}

Keywords: learning media, online, phet, static electricity, virtual lab

\section{PENDAHULUAN}

Pada akhir tahun 2019 tepatnya pada bulan Desember dunia digemparkan dengan kemunculan suatu virus baru yang bernama Covid-19, kasus pertama ditemukan di kota Wuhan, China sebelum akhirnya virus tersebut menyebar keseluruh penjuru dunia tanpa 
terkecuali Indonesia. Kasus pertama di Indonesia yang terinfeksi Covid-19 ditemukan pada pertengahan Maret 2020. Melihat virus tersebut yang terus menyebar ke masyarakat, kemudian pada awal bulan April pemerintah mengeluarkan kebijakan untuk menerapkan social distancing dan lockdown di beberapa daerah, selain itu pemerintah juga mengeluarkan surat keputusan yang memerintahkan kepada seluruh instansi pendidikan untuk melakukan pembelajaran daring.

Istilah daring berasal dari kata online yang tersusun atas dua kata yaitu on berarti hidup dan line berarti saluran (Marti dkk., 2016). Pengertian daring adalah suatu keadaan yang sedang menggunakan jaringan, terhubung dalam jaringan, satu perangkat dengan perangkat lainya yang saling terhubung sehingga bisa saling berkomunikasi. Pembelajaran daring sendiri bisa dikatakan pembelajaran jarak jauh melalui kegiatan virtual, dalam pembelajaran daring guru dan siswa dapat menggunakan berbagai aplikasi yang terdapat pada komputer, laptop dan juga handphone. Ketika pemerintah memerintahkan kepada seluruh instansi pendidikan untuk melaksanakan pembelajaran daring, banyak guru dan dosen yang berlomba-lomba mencari aplikasi yang tepat untuk pembelajaran mulai dari Whatsapp, Youtube, Edmodo, Classroom, bahkan Zoom. Tentunya pemilihan aplikasi tersebut tidak hanya dipilih berdasarkan kegunaannya saja tetapi juga aplikasi yang pilih dapat menarik minat peserta didik dalam pembelajaran daring. Akan tetapi berbeda halnya yang dilakukan oleh dosen program studi Tadris Ilmu Pengetahuan Alam Institut Agama Islam Negeri Jember yang mengampu mata kuliah Listrik Magnet mahasiswa Tadris IPA semester empat.

Pada mata kuliah Listrik Magnet mahasiswa dituntut untuk tidak hanya memahami teori saja tetapi juga memahami praktiknya, untuk memenuhi tuntutan belajar tersebut dosen pengampu mata kuliah menggunakan media pembelajaran Phet simulation dengan berbantuan aplikasi zoom pada materi listrik statis untuk mengganti tuntutan praktikum yang biasanya dilakukan di laboratorium kampus menjadi virtual lab menggunakan media pembelajaran Phet simulation. Laboratorium virtual adalah bentuk laboratorium dengan kegiatan pengamatan secara tidak langsung dengan bantuan software, semua peralatan yang diperlukan oleh sebuah laboratorium terdapat di dalam software tersebut (Saputra dkk., 2016). Tujuan penelitian ini yaitu (1) untuk mendeskripsikan media pembelajaran Phet sebagai penyedia kegiatan virtual lab pada mata kuliah listrik magnet, (2) untuk memaparkan pandangan mahasiswa terhadap kemenarikan media pembelajaran phet berbasis virtual lab pada materi listrik statis selama perkuliahan daring, (3) untuk merekomendasikan proses perkuliahan yang efektif berdasarkan persepsi mahasiswa menggunakan media pembelajaran Phet.

Media berasal dari bentuk jamak dari medium (perantara), berasal dari bahasa latin medium (antara) istilah ini mengarah pada segala sesuatu yang membawa informasi antara sumber dan sebuah penerima. Sedangkan media pembelajaran berarti segala sesuatu (orang, alat, bahan dan lingkungan) yang digunakan dalam pembelajaran untuk menyampaikan materi pembelajaran kepada peserta didik dan menstimulasi peserta didik dalam dalam belajar dan dalam mencapai tujuan belajar (Ratumanan \& Rosmiati, 2018).

Kriteria media pembelajaran yang baik antara lain:

1. Media pembelajaran harus sesuai dengan tujuan yang ingin dicapai apakah tujuan tersebut bersifat kognitif, afektif, atau psikomotorik.

2. Media pembelajaran harus memiliki konsep yang jelas artinya pemilihan media pembelajaran tidak hanya terbatas pada kesenangan ataupun ketertarikan siswa tetapi juga harus menjadi bagian yang integral yang dapat meningkatkan efektivitas dan efisiensi pembelajaran siswa.

3. Media pembelajaran harus sesuai dengan karakteristik siswa.

4. Media pembelajaran harus cocok dengan gaya belajar siswa serta kemampuan pendidik. 
5. Media pembelajaran harus sesuai dengan kondisi, fasilitas, serta waktu yanng tersedia.

Media pembelajaran yang menarik dapat menumbuhkan minat mahasiswa terhadap suatu konsep. Media Phet simulation merupakan media pembelajaran berupa rangkaian peralatan laboratorium berbentuk software komputer berbasis multimedia interaktif yang dapat mensimulasikan kegiatan di laboratorium seakan-akan pengguna menggunakan alat ptaktikum yang sebenarnya (Muzana \& Astuti, 2017). Pada awalnya Phet dibuat untuk proses belajar mengajar fisika, namun dalam perkembangannya simulasi Phet juga disediakan untuk pengajaran kimia, biologi, ilmu bumi, matematika, dan ilmu lainnya (Adams, W. K.,2010). Media pembelajaran Phet simulation diciptakan oleh komuitas sains melalui phet project di University Of Colorado.

Pendekatan penggunaan pembelajaran menggunan simulasi seperti Phet, dapat menekankan situasi konflik pada diri mahasiswa, yaitu dengan menampilkan fakta-fakta yang berupa eksperimen, demonstrasi, atau data-data hasil percobaan yang bertentangan dengan konsepsi mahasiswa akan menciptakan proses pembelajaran yang yang jauh lebih baik (Finkelstein dkk., 2006). Hal ini sesuai dengan pernyataan Martínez dkk. (2011) yang menyatakan bahwa simulasi komputer dapat menciptakan proses pembelajaran yang jauh lebih efisien dan dapat diterapkan pada masalah atau situasi dunia nyata, sehingga dapat meningkatkan kemampuan penguasaan konsep mahasiswa. Simulasi Phet dapat menekankan pada korespondensi antara fenomena nyata dan simulasi komputer dengan menyajikan model-model konseptual fisik yang mudah dipahami oleh para siswa (Destini, 2019).

Penggunaan media pembelajaran Phet untuk kegiatan virtual lab selama pembelajaran daring memiliki fungsi seperti meningkatkan pengetahuan (konsep produk IPA), metode ilmiah (meliputi kegiatan mengamati, mengklasifikasi, mengukur, merumuskan masalah, merumuskan hipotesis, mengidentifikasi variabel, merancang eksperimen, menginterpretasikan data, menyimpulkan dan mengkomunikasikan melalui eksperimen maya) dan sikap ilmiah karakter siswa (D. P. Sari \& Lutfi, 2013). Selain itu penggunaan media pembelajaran Phet untuk kegiatan virtual lab selama pembelajaran daring juga dapat digunakan guru dalam menjelaskan materi ataupun juga dapat digunakan untuk pengerjaan soal atu latihan untuk siswa.

Dalam penelitian yang dilakukan oleh Maryam (2019) kepada siswa kelas XI Miskawaih dengan membandingkan kelas kontrol dan kelas ekperimen yang menggunakan Phet untuk kegiatan virtual lab, yang mana diperoleh hasil bahwa kelas kontrol memperoleh nilai pretest sebesar 65 dan nilai posttest sebesar 68, sedangkan pada kelas eksperimen diperoleh hasil pretest sebesar 50 dan nilai posttest sebesar 82 dari data tersebut dapat disimpulkan bahwa penggunaan Phet untuk kegiatan virtual lab berperan untuk meningkatkan hasil belajar siswa hal tersebut terlihat dari adanya peningkatan nilai posttest dan pretest kelas eksperimen yang cukup signifikan. Selain itu penelitian lain yang dilakukan oleh Ardianti (2020) dengan membandingkan kelas kontrol dan kelas uji dan diperoleh hasil bahwa terdapat peningkatan pemahaman konsep kelas eksperimen sebesar $82 \%$ dan kelas kontrol sebesar $52 \%$ dari hasil tersebut dapat digambarkan bahwa penggunaan media Phet dalam materi listrik statis untuk kegiatan virtual lab dapat meningkatkan pemahaman konsep. Hermanto, dkk. (2013) menyatakan bahwa penguasaan konsep merupakan pemberian tanda pada suatu obyek untuk membantu seseorang mengerti dan paham terhadap obyek tertentu.

Cara penggunaan media pembelajaran phet sebagai berikut:

1. Buka gogle pada laptop ataupun pada handphone,

2. Masuk pada website https://phet.colorado.edu/in/simulations/category/physics pada google.

3. Selanjutnya akan muncul tampilan menu berbagai percobaan, pilih menu percobaan yang dibutuhkan jika yang ingin dipraktikumkan terkait materi listrik statis maka

Alfarizi, Rivo K, dkk.: Analisis Kemenarikan Media Pembelajaran Phet Berbasis Virtual Lab Pada Materi Listrik Statis Selama Perkuliahan Daring Ditinjau Dari Perspektif Mahasiswa |21 
dapat memilih percobaan John Travoltage, balon dan listrik statis ataupun menu yang sesuai dengan materi tersebut.

4. Buka menu yang dipilih, maka akan muncul kata unduh atau mulai.

5. Percobaan pada Phet bisa dengan mengunduh terlebih dahulu ataupun menggunakan percobaan langsung tanpa diunduh.

6. Percobaan siap untuk digunakan.

Menurut Ali (2019) Penggunaan media pembelajaran Phet dalam kegiatan virtual

lab memiliki kelebihan antara lain:

1. Mengurangi keterbatasan waktu, dengan penggunaan media pembelajaran sebagai virtual lab tidak tebatas waktu artinya dalam melaksanakan praktikum tidak perlu takut akan kehabisan waktu karena media pembelajaran Phet dapat digunakan kapan saja.

2. Mengurangi hambatan geografi, jika terdapat siswa atau mahasiswa yang berlokasi cukup jauh dari pusat pembelajaran.

3. Ekonomis, tidak membutuhkan ruang khusus seperti laboratorium dan juga tidak memerlukan alat-alat praktikum.

4. Meningkatkan kualitas percobaan, karena melalui Phet dapat mengulang percobaan jika terdapat keraguan terhadap hasil yang diperoleh ketika percobaan awal.

5. Meningkatkan keamanan dan keselamatan siswa karena penggunaan Phet untuk kegiatan virtual lab tidak memerlukan alat-alat yang berbahaya.

Lebih lanjut Ali (2019) juga mengemukakan kelemahan media pembelajaran Phet untuk virtual lab antara lain:

1. Keterbatasan pemahaman cara penggunaan Phet karena pada tampilan phet sendiri menggunakan bahasa inggris.

2. Kurangnya pemahaman secara riil di laboratorium nyata, sehingga terjadi kebingungan peserta didik dalam mengakses dan memproses simulasi tersebut.

3. Tidak mengetahui alat dan bahan secara riil yang biasanya digunakan dalam praktikum karena didalam aplikasi Phet yang digunakan hanyalah alat dan bahan berupa animasi.

4. Tidak memberikan pengalaman dilapangan secara nyata.

\section{METODE}

Metode yang digunakan dalam penelitian ini adalah berupa survei dengan memberikan angket kepada mahasiswa Tadris Ilmu Pengetahuan Alam Institut Agama Islam Negeri Jember semester 4 yang sedang menempuh materi listrik statis pada mata kuliah Listrik Magnet, pengisian angket dilakukan secara online melalui google form yang diberikan kepada masing-masing mahasiswa Tadris Ilmu Pengetahuan Alam angkatan 2018. Angket merupakan metode pengumpulan data melalui faktor pernyataan yang diisi oleh para responden. Teknik analisis data yang digunakan adalah teknik analisis deskriptif kuantitatif, dengan menggunakan skala Likert. Skala Likert adalah skala pengukuran yang dikembangkan Likert, yang mana pada skala Likert mempunyai empat butir soal atau lebih yang dikombinasikan sehingga membentuk skor atau nilai yang menggambarkan sifat, pengetahuan serta respon individu (Subroto \& Haviana, 2016).

Adapun angket penilaian kemenarikan media pembelajaran Phet berbasis virtual lab meliputi desain tampilan media pembelajaran Phet, konten materi, isi media pembelajaran Phet, pemenuhan kebutuhan belajar mahasiswa, Respon mahasiswa terhadap Phet untuk kegiatan virtual lab selama perkuliahan daring. Adapun langkahlangkah dalam penelitian meliputi: 


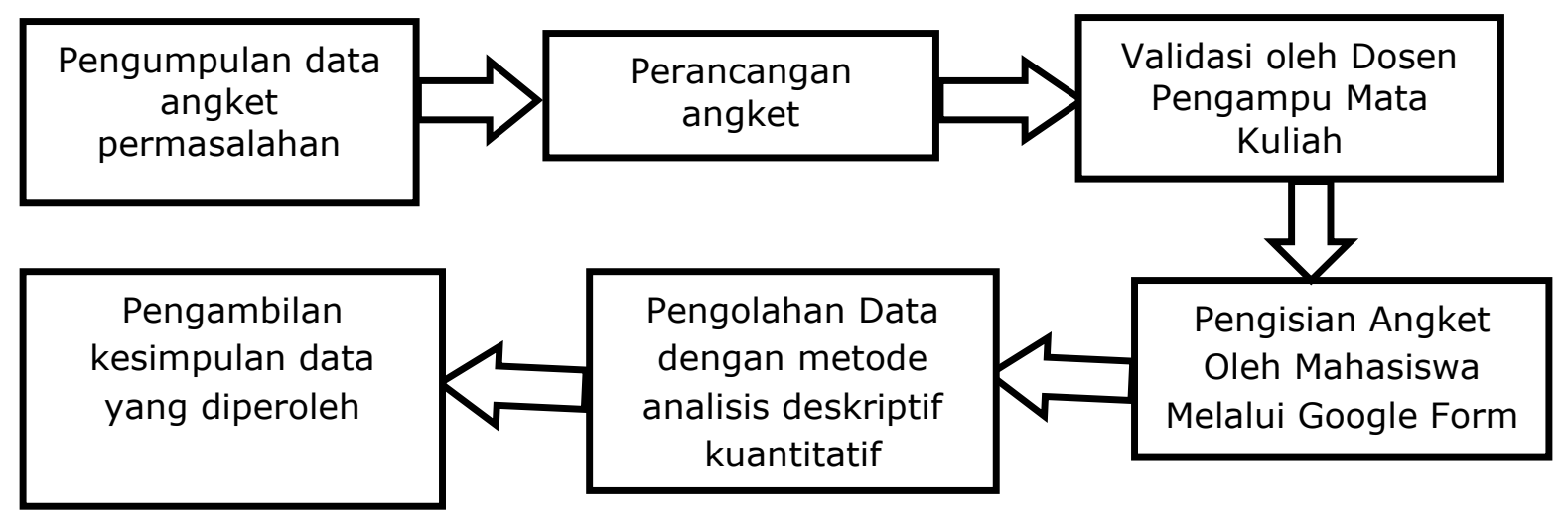

HASIL DAN PEMBAHASAN

Dari penelitian yang dilakukan diperoleh hasil kemenarikan yang bagus pada setiap indikator, baik indikator desain tampilan media pembelajaran Phet, konten materi, kualitas isi Phet, maupun pemenuhan kebutuhan belajar. Pemilihan indikator kemenarikan media pembelajaran Phet disesuaikan dengan kriteria pemilihan media yang baik menurut Ratumanan (2018) yang mana media pembelajaran yang baik harus sesuai dengan tujuan pembelajaran, memiliki konsep yang jelas, sesuai dengan karakteristik siswa, dan sesuai dengan kondisi. Hasil penelitian terlihat pada tabel berikut:

Tabel 1. Penilaian kemenarikan media pembelajaran Phet berbasis virtual lab pada materi listrik statis selama perkuliahan daring.

\begin{tabular}{|c|c|c|c|c|c|}
\hline No. & Indikator & jumlah & Rata-rata & Presentase & Kategori \\
\hline 1. & $\begin{array}{l}\text { Desain } \\
\text { tampilan } \\
\text { Phet }\end{array}$ & 562 & 9,21 & $77 \%$ & Bagus \\
\hline 2. & $\begin{array}{l}\text { Konten } \\
\text { materi }\end{array}$ & 1499 & 24,57 & $68 \%$ & Bagus \\
\hline 3. & Isi Phet & 193 & 12,07 & $75 \%$ & Bagus \\
\hline 4. & $\begin{array}{l}\text { Pemenuhan } \\
\text { kebutuhan } \\
\text { belajar }\end{array}$ & 371 & 6,08 & $76 \%$ & Bagus \\
\hline & Rata-rata & 656 & 13 & $73 \%$ & Bagus \\
\hline
\end{tabular}

Hasil penelitian menunjukkan untuk indikator kemenarikan terhadap desain tampilan media pembelajaran Phet memiliki presentase sebesar $77 \%$ hal tersebut tampak dari jawaban mahasiswa yang menganggap bahwa media pembelajaran Phet memiliki tampilan awal yang menarik. Karena tampilan awal media pembelajaran Phet disajikan dengan animasi yang mampu membuat pengguna tidak bosan dan dapat

Alfarizi, Rivo K, dkk.: Analisis Kemenarikan Media Pembelajaran Phet Berbasis Virtual Lab Pada Materi Listrik Statis Selama Perkuliahan Daring Ditinjau Dari Perspektif Mahasiswa |23 
menggugah antusias dalam belajar. Hasil indikator desain tampilan media pembelajaran Phet yang menarik sesuai dengan penelitian yang dilakukan oleh Sudjito \& Sudarmi (2016) dalam penelitiannya tentang penggunaan Phet pada materi medan listrik yang dilakukan kepada mahasiswa yang sedang menempuh materi medan listrik yang mana hasil kuisioner menunjukkan $100 \%$ mahasiswa sangat antusias dalam belajar dengan memanfaatkan media pembelajaran Phet karena media pembelajaran Phet mampu melibatkan indera penglihatan mahasiswa dengan gambar-gambar yang menarik sehingga mahasiswa menikmati dalam mengikuti pembelajaran. Hal tersebut juga berkaitan dengan penelitian yang dilakukan oleh Nurhasanah \& Supardi (2014) mengatakan Phet simulation memiliki tampilan yang menyenangkan, bisa bergerak dan menarik, memungkinkan media ini layak digunakan sebagai media mengajar anak-anak tuna rungu yang menggunakan kemampuan indra penglihatan lebih utama dibandingkan dengan kemampuan indera pendengaran.

Pada indikator kemenarikan konten materi percobaan media pembelajaran Phet juga memiliki hasil yang bagus dengan presentase sebesar $68 \%$, kemenarikan konten materi percobaan Phet untuk kegiatan virtual lab selama perkulihan daring dikarenakan praktikum virtual yang disajikan pada website Phet sesuai dengan konsep, tujuan dan kebutuhan dalam pembelajaran materi listrik statis selain itu pengguna dapat memilih beberapa percobaan yang tertera pada phet seperti percobaan John Travoltage, percobaan balon dan listrik statis yang memungkinkan bagi pengguna untuk memperoleh hal-hal baru serta iformasi baru. Terkait konten materi pembelajaran Phet sesuai dengan penelitian yang dilakukan oleh Ahadia \& Widodo (2016) yang mana dalam penelitiannya untuk aspek kesesuain Phet dengan materi listrik statis diperoleh hasil sangat layak dikarenakan pada aplikasi Phet percobaan sesuai dengan isi, konsep, tujuan pendidikan yang mampu meningkatkan hasil belajar dan menumbuhkan rasa ingin tahu. Dengan menggunakan media pembelajaran Phet diharapkan mahasiswa mampu dan dapat menerapkan konsep yang telah diperoleh selama pembelajaran secara teori dan praktikum ke simulasi yang terdapat dalam media Phet tersebut.

Pada indikator kemenarikan isi percobaan Phet memiliki diperoleh hasil yang bagus dengan presentase sebesar $75 \%$ kemenarikan perocobaan terlihat pada isi percobaan media pembelajaran Phet yang mudah dipahami oleh pengguna dan juga mampu menumbuhkan rasa semangat pengguna untuk mencoba percobaan yang disediakan pada media pembelajaran Phet, selain itu media pembelajaran Phet juga memungkinkan pengguna untuk mengulang percobaan apabila dalam percobaan sebelumnya belum menemukan hasil atau masih ragu terhadap hasil yang diperoleh, hal tersebut sebanding dengan penelitian yang dilakukan oleh Ali (2019) yang mengemukakan bahwa salah satu kelebihan media pembelajaran Phet adalah meningkatkan kualitas percobaan yang memungkinkan pengguna mengulang percobaan jika terdapat keraguan terhadap hasil yang diperoleh pada percobaan awal.

Indikator pemenuhan kebutuhan belajar juga memiliki kemenarikan yang bagus dengan presentase sebesar $76 \%$, hal ini dikarenakan media pembelajaran Phet mampu memenuhi kebutuhan praktik mahasiswa terkait materi listrik statis yang mana dalam materi listrik statis diperlukan beberapa percobaan yang biasanya dilakukan secara langsung di laboratorium kampus dan sebagai pengganti akan kebutuhan praktik selama perkuliahan daring media pembelajaran Phet dapat memenuhi kebutuhan tersebut. Media pembelajaran Phet ini juga dapat memenuhi kebutuhan belajar mahasiswa, yang mana materi yang awalnya sulit menjadi mudah sehingga mahasiswa mampu memvisualisasikan pemahaman terhadap materi yang diajarkan. Hal ini selaras dengan penelitian yang dilakukan oleh Adams dkk., (2008) mengatakan bahwa simulasi Phet mampu memvisualisasikan dengan baik konsep materi yang awalnya sulit dipahami ketika pembelajaran disajikan dengan metode ceramah. Hasil penelitian dapat digambarkan pada diagram berikut. 


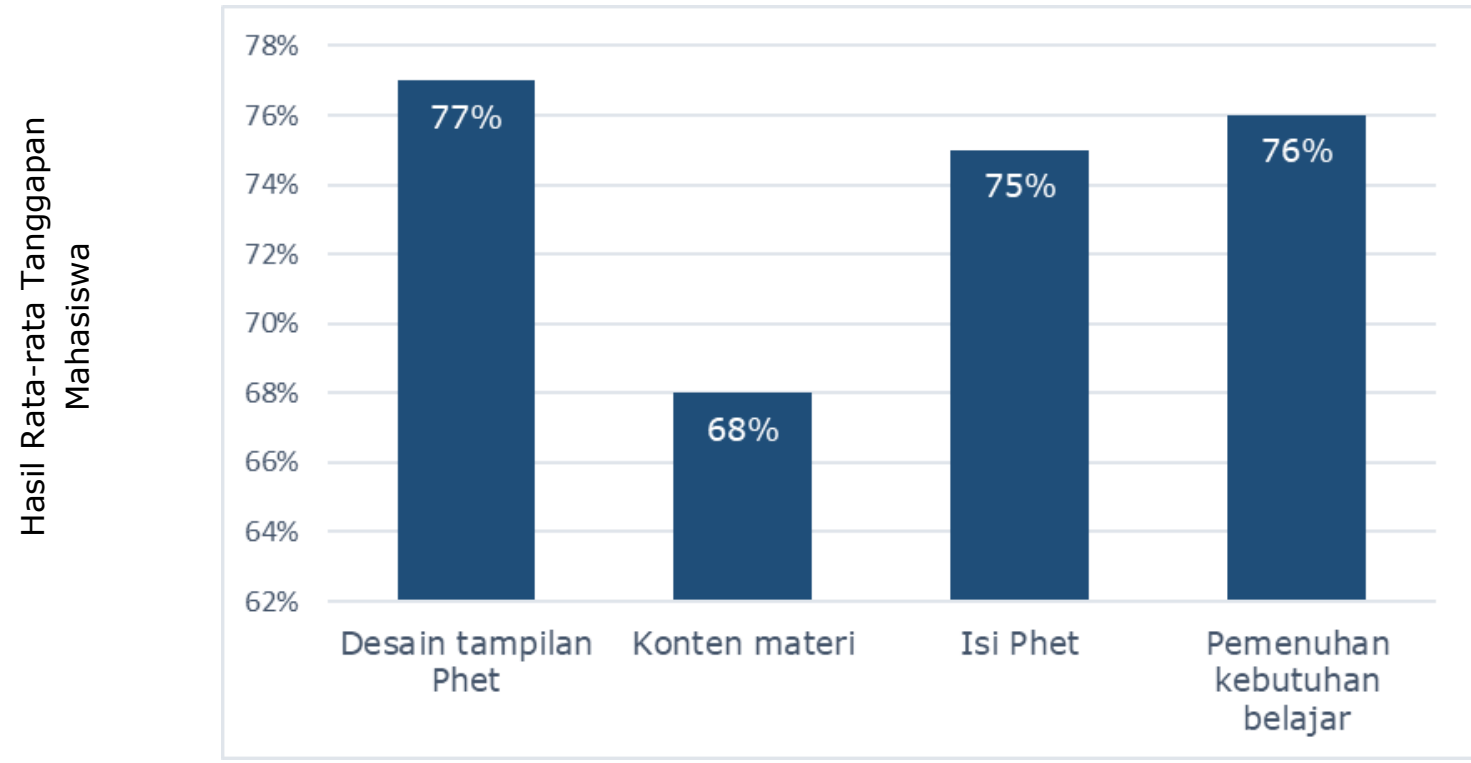

Gambar 1. Tanggapan mahasiswa tiap indikator pernyataan

Disisi lain respon positif ditunjukkan oleh mahasiswa dalam menggunakan media pembelajaran Phet pada materi listrik statis, mahasiswa merasa media pembelajaran Phet dalam kegiatan virtual lab selama pembelajaran daring sangat efektif untuk menggantikan kegiatan praktikum yang biasanya dilakukan di laboratorium kampus. Hal ini sebanding dengan penelitian yang dilakukan oleh Prihatiningtyas dkk., (2013) menjelaskan bahwa media pembelajaran Phet lebih efiseien jika dibandingkan dengan menggunakan KIT sederhana dalam membantu peserta didik untuk menguasai konsep konten fisika yang bersifat abstrak. Sebagian besar mahasiswa mengatakan bahwa pembelajaran listrik statis menggunakan media Phet simulation dapat meningkatkan hasil belajarnya. Hal ini selaras dengan penelitian yang dilakukan oleh Saregar (2016) yang menyatakan pembelajaran fisika kuantum dengan memanfaatkan media pembelajaran Phet berdampak positif pada hasil belajar siswa.

Dalam penelitian sebelumnya juga menunjukkan bahwa penggunaan media yang dilengkapi dengan Phet dapat meningkatkan hasil belajar siswa (Wicaksono \& Haryudo, 2016). Dengan menggunakan media pembelajran berbasis Phet simulation pada materi listrik statis, sebagian mahsiswa lebih minat belajar fisika dan pembelajaran tidak akan menjadi bosan lagi. Hal ini selaras dengan penelitian yang dilakukan oleh Saregar (2016) bahwa minat belajar fisika mahasiswa dalam pembelajaran dengan pendekatan minat cukup signifikan, meskipun sebelumnya beberapa mahasiswa merasa bosan dengan pembelajaran yang selalu dilakukan dengan kerja kelompok. Penggunaan media pembelajaran Phet pada materi listrik statis dapat meningkatkan kemampuan berpikir tingkat tinggi bagi mahasiswa. Pernyataan tersebut sesuai dengan penelitian yang dilakukan oleh Wieman \& Perkins (2006) bahwa penggunaan simulasi Phet dalam pembelajaran sering kali mengarah pada pernyataan yang melatih kemampuan berpikir tingkat tinggi pada peserta didik. Selain itu penggunaan media pembelajaran Phet untuk kegiatan virtual lab juga mudah digunakan dan sangat efisien dalam hal waktu dan tempat karena dapat digunakan kapan saja dan dimana saja, meskipun dalam penggunaannya media pembelajaran Phet harus terhubung dengan internet tetapi penggunaannya minim terhadap kuota.

Hal tersebut selaras dengan dengan pemikiran Ali (2019) yang mengatakan bahwa media pembelajaran Phet memiliki kelebihan dalam mengurangi keterbatasan

Alfarizi, Rivo K, dkk.: Analisis Kemenarikan Media Pembelajaran Phet Berbasis Virtual Lab Pada Materi Listrik Statis Selama Perkuliahan Daring Ditinjau Dari Perspektif Mahasiswa |25 
waktu, mengurangi keterbatasan geografi, bersifat ekonomis dan memiliki kualitas percobaan yang bagus serta mampu menjaga keselamatan pengguna. Akan tetapi dibalik kemudahan penggunaan media pembelajaran Phet mahasiswa memerlukan pedoman penggunaan media pembelajaran Phet dari dosen pengampu mata kuliah, dikarenakan beberapa mahasiswa belum mengerti maksud dan langkah-langkah percobaan menggunakan media pembelajaran Phet, pemberian pedoman penggunaan media pembelajaran Phet juga nantinya berpengaruh terhadap mahasiswa dalam memahami materi yang diuji cobakan. Selain itu, kendala yang dihadapi dalam menerapkan pembelajaran menggunakan media pembelajaran Phet yaitu pemadaman listrik, Hal itu tentunya berpengaruh dalam kegiatan belajar.

Purwanto \& Hendri (2016) menyatakan bahwa salah satu kendala yang dihadapi yaitu ketika di sekolah terkena giliran pemadaman listrik. Pemadaman ini terjadi karena adanya perbaikan dari pusat penyuplai daya listrik, dimana pemadaman tersebut tidak dapat diprediksikan yang tentunya berpengaruh pada proses kegiatan belajar mengajar di kelas eksperimen satu karena media pembelajaran Phet memerlukan energi listrik dalam pengaplikasiannya. Selain itu kelemahan media pembelajaran Phet pembelajaran yakni belum dilengkapi dengan lembar kerja mahasiswa (LKM). Mengatasi kelemahan tersebut ada penelitian yang dilakukan oleh A. K. Sari dkk. (2015) berhasil mengembangkan lembar kerja peserta didik berbasis Phet dengan hasil yang sangat menarik, mudah, dan sangat bermanfaat, serta produk efektif sebagai media pembelajaran dengan presentase penguasaan konsep peserta didik lebih dari $80 \%$ telah mencapai kelulusan dalam aspek kognitif maupun afektif.

Lebih lanjut mahasiswa merekomendasikan penggunaan media pembelajaran Phet dalam pembelajaran, tidak hanya digunakan dalam pembelajaran materi listrik statis saja tetapi juga dapat diterapkan pada pembelajaran IPA lain seperti kimia pada jenjang pendidikan SMP, SMA, maupun perguruan tinggi. Jika melihat hasil dari keempat indikator tersebut yang memiliki rata-rata presentase sebesar $73 \%$, maka media pembelajaran Phet untuk kegiatan virtual lab pada materi listrik statis selama perkuliahan daring menarik untuk digunakan. Untuk meningkatkan kemaksimalan penggunaan media pembelajaran Phet guru dapat memberikan modul terkait pedoman penggunaan, serta guru dapat memberikan simulasi terlebih dahulu dengan membuat video tutorial penggunaan dan penjelasan, kemudian video tersebut diupload ke youtube, atau guru juga dapat menggunakan software bandicam yang terhubung dengan aplikasi zoom yang kemudian guru mengadakan tatap muka melalui aplikasi zoom untuk menjelaskan terkait penggunaan media pembelajaran Phet kepada siswa dengan maksud agar peserta didik mengetahui cara penggunaaan media pembelajaran Phet untuk kegiatan virtual lab sehingga pembelajaran dapat berjalan dengan maksimal.

\section{KESIMPULAN}

Berdasarkan hasil penelitian diatas dapat disimpulkan bahwa kemenarikan media pembelajaran Phet untuk kegiatan virtual lab pada materi listrik statis selama perkuliahan daring menarik untuk digunakan baik oleh dosen maupun mahasiswa. Hal tersebut ditinjau dari hasil indikator kemenarikan baik dari desain tampilan Phet, konten materi, isi percobaan media pembelajaran Phet, serta kebutuhan belajar, yang mana pada masing-masing indikator memiliki kriteria yang bagus, kelebihan media pembelajaran Phet antara lain dapat memenuhi kebutuhan praktik mahasiswa, menggugah antusias belajar mahasiswa, meningkatkan pemahaman mahasiswa terhadap materi. Sedangkan kelemahan media pembelajaran Phet yaitu mahasiswa kurang memahami alat-alat praktikum secara riil, kurangnya pengalaman praktikum langsung, diperlukan adanya cara penggunaan dari guru. Sedangkan dalam penggunaan media pembelajaran Phet pada materi listrik statis mahasiswa memberikan respon yang positif 
karena dalam menggunakan media pembelajaran Phet, mahasiswa dapat memahami materi dengan mudah dan sangat efektif untuk menggantikan kegiatan prsktikum yang biasanya dilakukan di laboratorium kampus, selain itu mahasiswa juga merekomendasikan agar media pembelajaran Phet dapat digunakan pada mata pelajaran IPA yang lain seperti kimia, biologi dan fisika pada jenjang SMP, SMA dan juga perguruan tinggi, untuk memaksimalkan penggunaan media pembelajaran Phet diperlukan adanya buku pedoman tata cara penggunaan media pembelajaran Phet dari guru serta video tutorial dari guru bisa melalui youtube atau melalui bantuan software bandicam.

\section{UCAPAN TERIMAKASIH}

Ucapan terimakasih disampaikan kepada wakil rektor III IAIN Jember, dosen ahli pengampu mata kuliah listrik magnet IAIN Jember, mahasiswa Tadris IPA angkatan 2018 IAIN Jember, serta tim penulis jurnal yang turut berkontribusi dalam kegiatan pembuatan jurnal sehingga kegiatan ini dapat berjalan dengan baik, lancar dan sukses.

\section{DAFTAR PUSTAKA}

Adams, W. K. (2010). Student engagement and learning with Phet interactive simulations. Il Nuovo Cimento, 33(3), 21-32.

Adams, W. K., Reid, S., LeMaster, R., McKagan, S., Perkins, K., Dubson, M., \& Wieman, C. E. (2008). A study of educational simulations Part II-Interface Design. Journal of Interactive Learning Research, 19(4), 551-577.

Ahadia, L., \& Widodo, W. (2016). Kelayakan Kit Praktikum Sederhana Sebagai Media Pembelajaran pada Materi Listrik Statis. 7.

Ali, A. (2019). Mahasiswa Fakultas Tarbiyah dan Keguruan Prodi Pendidikan Fisika. 90.

Ardianti, O. (2020). Jurnal Dedikasi Pendidikan. 4(1), 6.

Destini, R. (2019). Penerapan Kolaborasi Media Interaktif Phet dan Powerpoint pada Pelajaran Fisika Sma Di Kota Medan. 6.

Marti, N. W., Aryanto, K. Y. E., \& Setemen, K. (2016). Sistem Pembimbingan dalam Jaringan (Daring) Proses Penyusunan Skripsi Dan Tugas Akhir Mahasiswa di Universitas Pendidikan Ganesha. 5.

Martínez, G., Naranjo, F. L., Pérez, Á. L., Suero, M. I., \& Pardo, P. J. (2011). Comparative study of the effectiveness of three learning environments: Hyperrealistic virtual simulations, traditional schematic simulations and traditional laboratory. Physical Review Special Topics - Physics Education Research, 7(2), 020111. https://doi.org/10.1103/PhysRevSTPER.7.020111

Maryam, E. (2019). Pengaruh Laboratorium Virtual terhadap Prestasi Fisika pada Pokok Bahasan Listrik Statis. 7, 9.

Muzana, S. R., \& Astuti, D. (2017). Penerapan Pembelajaran Berbasis Simulasi Phet untuk Meningkatkan Pemahaman Konsep Fisika Inti pada Siswa SMA. 9.

Nurhasanah, A., \& Supardi, Z. A. I. (2014). Pemanfaatan Media Visualisasi Phet Simulations sebagai Upaya Mengatasi Kesulitan Belajar Siswa Tunarungu pada Materi Listrik Dinamis. 03(02), 6.

Purwanto, A. E., \& Hendri, M. (2016). Studi Perbandingan Hasil Belajar Siswa Menggunakan Media Phet Simulations dengan Alat Peraga pada Pokok Bahasan Listrik Magnet Di Kelas IX SMPN 12 Kabupaten Tebo. Jurnal Pendidikan Fisika, $01(01), 6$.

Ratumanan, Rosmiati I. (2008). Perencanaan Pembelajaran. Depok: PT. Raja Grafindo

Saregar, A. (2016). Pembelajaran Pengantar Fisika Kuantum dengan Memanfaatkan Media Phet Simulation dan LKM Melalui Pendekatan Saintifik: Dampak pada Minat

Alfarizi, Rivo K, dkk.: Analisis Kemenarikan Media Pembelajaran Phet Berbasis Virtual Lab Pada Materi Listrik Statis Selama Perkuliahan Daring Ditinjau Dari Perspektif Mahasiswa |27 
dan Penguasaan Konsep Mahasiswa. Jurnal Ilmiah Pendidikan Fisika Al-Biruni, 5(1), 53. https://doi.org/10.24042/jpifalbiruni.v5i1.105

Sari, A. K., Ertikanto, C., \& Suana, W. (2015). Pengembangan LKS Memanfaatkan Laboratorium Virtual Pada Materi Optik Fisis Dengan Pendekatan Saintifik. 12.

Sari, D. P., \& Lutfi, A. (2013). Uji Coba Pembelajaran Ipa dengan LKS sebagai Penunjang Media Virtual Phet untuk Melatih Keterampilan Proses pada Materi Hukum Archimedes. 01, 6.

Subroto, I. M. I., \& Haviana, S. F. C. (2016). Sistem Informasi Angket Pengukuran Skala Kebutuhan Materi Pembelajaran Tambahan Sebagai Pendukung Pengambilan Keputusan Di Sekolah Menengah Atas Menggunakan Skala Likert. 1(2), 12.

Sudjito, D. N., \& Sudarmi, M. (2016). Desain Pembelajaran dengan Menggunakan Media Simulasi. 12.

Wicaksono, A., \& Haryudo, S. I. (2016). Penerapan Problem Based Instruction (PBI) dengan Media Software Phet untuk Meningkatkan Hasil Belajar Siswa Pada Mata Pelajaran Dasar Dan Pengukuran Listrik Berbasis Kurikulum 2013 Kelas X Tiptl di SMK Negeri 5 Surabaya. 05, 8.

Wieman, C. E., \& Perkins, K. K. (2006). A powerful tool for teaching science. Nature Physics, 2(5), 290-292. https://doi.org/10.1038/nphys283. 